\title{
Sexual dimorphism of mandibular measures from computed tomographies
}

\author{
Dimorfismo sexual de medidas mandibulares a partir \\ de tomografias computadorizadas
}

\author{
Renato Taqueo Placeres ISHIGAME ${ }^{1}$ iD 0000-0002-9576-4999 \\ Alicia PICAPEDRA² iD 0000-0003-0166-1145 \\ Carlos SASSI2 iD 0000-0002-8715-4672 \\ Viviane ULBRICHT ${ }^{1}$ iD 0000-0001-7441-7667 \\ Vanessa Gallego Arias PECORARI ${ }^{3}$ iD 0000-0002-0300-5697 \\ Francisco HAITER NETO4 ${ }^{4}$ 0000-0002-5610-8307 \\ Eduardo DARUGE JÚNIOR' ${ }^{1}$ 0000-0001-6565-3203 \\ Luiz FRANCESQUINI JÚNIOR' ${ }^{1}$ iD 0000-0002-6344-3488
}

\section{ABSTRACT}

Objetive: The objective of this study was to analyze mandibular measurements obtained from 225 computed tomography scans of the Osteological and CT Biobanks of Faculdade de Odontologia de Piracicaba Universidade Estadual de Campinas, aiming to verify the existence of a relationship between these measures and sexual dimorphism and ancestry. Methods: We sought to establish a mathematical model capable of estimating sex and ancestry. Of these scans, 126 were male, 94 were female and 5 were unidentified, aged 15 to 100 years, and ancestry known for the skin color phenotype (white, black, brown and yellow). Measurements were made between the following points: right lateral condylion and left lateral condylion; right lateral condylion and pogonion; left lateral condylion and pogonion; mesial border of right mental foramen and mesial border of left mental foramen. The area delimited by the triangle formed by the measurements between right lateral condylion and left lateral condylion was also analyzed; right lateral condylion and pogonion; and left lateral condylion and pogonion. Student t test for homogeneous variances showed that there was statistical difference in the means as a function of sex, except for the area measure, which was not used in the model. Results: It was possible to establish a mathematical model with accuracy of $69.2 \%$. There was no statistical difference in the averages as a function of ancestry. Conclusion: It is concluded that the measures investigated help

\footnotetext{
1 Universidade Estadual de Campinas, Faculdade de Odontologia de Piracicaba, Departamento de Odontologia Social, Área de Odontologia Legal e Deontologia. Av. Limeira, 901, Vila Areião, 13414-903, Piracicaba, SP, Brasil. Correspondência para / Correspondence to: RTP ISHIGAME. E-mail: <renatotaqueo@yahoo.com>.

2 Universidad de la República, Facultad de Odontología. Montevideo, Uruguai.

${ }^{3}$ Faculdade São Leopoldo Mandic, Instituto de Pesquisas São Leopoldo Mandic. Campinas, SP, Brasil.

4 Universidade Estadual de Campinas, Faculdade de Odontologia de Piracicaba, Departamento de Diagnóstico Oral. Piracicaba, SP, Brasil.

$\boldsymbol{\nabla} \boldsymbol{\nabla} \boldsymbol{\nabla}$

How to cite this article

Ishigame RTP, Palomeque AMP, Etchegoyen CAS, Pecorari VGA, Haiter Neto F, Daruge Júnior E, Francesquini Júnior L. Sexual dimorphism of mandibular measures from computed tomographies. RGO, Rev Gaúch Odontol. 2019;67:e201907. http://dx.doi.org/10.1590/1981-86 37 2019000073579
} 
in the process of estimating sex, but were not adequate to estimate ancestry. The proposed methodology should be expanded to other population groups so that it can be improved.

Indexing terms: Anthropometry. Forensic dentistry. Sex characteristics. Tomography, X-ray computed.

\section{RESUMO}

Objetivo: Analisar medidas mandibulares obtidas de 225 tomografias computadorizadas do "Biobanco Osteológico e Tomográfico da Faculdade de Odontologia de Piracicaba Universidade Estadual de Campinas", visando verificar a existência de relação entre essas medidas, o dimorfismo sexual e a ancestralidade. Métodos: Buscou-se estabelecer um modelo matemático capaz de estimar sexo e ancestralidade. Destas tomografias, 126 eram do sexo masculino, 94 do sexo feminino e 5 estavam sem identificação, com idades entre 15 e 100 anos, e ancestralidade conhecida para o fenótipo cor da pele (branco, negro, pardo e amarelo). Foram realizadas medidas entre os pontos: kondylion lateral direito e kondylion lateral esquerdo; kondylion lateral direito e pogônio; kondylion lateral esquerdo e pogônio; borda mesial do forame mentoniano direito e borda mesial do forame mentoniano esquerdo. Analisou-se também a área delimitada pelo triângulo formado pelas medidas entre kondylion lateral direito e kondylion lateral esquerdo; kondylion lateral direito e pogônio; e kondylion lateral esquerdo e pogônio. O teste t de Student para variâncias homogêneas demonstrou que houve diferença estatística nas médias em função do sexo, à exceção da medida de área, que não foi utilizada no modelo. Resultados: Foi possível estabelecer um modelo matemático com acurácia de 69,2\%. Não houve diferença estatística nas médias em função da ancestralidade. Conclusão: Conclui-se que as medidas investigadas auxiliam no processo de estimativa do sexo, porém não foram adequadas para estimar a ancestralidade. A metodologia proposta deve ser expandida para outros grupos populacionais para que possa ser aperfeiçoada.

Termos de indexação: Antropometria. Odontologia legal. Caracteres sexuais. Tomografia computadorizada por raios $X$.

\section{INTRODUCTION}

The identification process uses a set of replicable methodologies that aim to establish positive identification of a skeleton or bone fragment [1]. Such methods include the study of dental characteristics and DNA, antemortem and post-mortem, known as primary methods of identification $[2,3]$. To facilitate, the identificatory process starts with anthropometric study, which provides indicative information that will direct the exams to be conducted $[1,4]$.

It should also be noted that Anthropometry can be used in Pediatrics (child health indicators, age, weight, height) [5], in sports medicine (physical performance) [6], ergonomics [7], and forensic sciences with Forensic Dentistry and Forensic Medicine.

In criminal investigations, the victim may be in an advanced state of decomposition, skeletonized, carbonized, among others [8-11].

Through the systematic review [10] focusing on assisting method in human identification between 1997 to 2007, it was concluded that numerous radiological techniques can be used for human identification in determination of sex, ancestry, and age.

These studies were enhanced with the advent of the use of computed tomography in forensic sciences
[4] and it can be used in virtually any area of the human body. New technologies, particularly 3D images, are being gradually incorporated into routines in cases of human identification, autopsies, among others.

Cranium and mandible are by election the bones most studied by dental surgeons and in this same sequence are the most found at crime scenes [4].

Of these, the mandible is the largest, most solid facial bone, and often that which is more resistant to postmortem damage, in addition it is important element for estimation of sexual dimorphism [12-16].

Considering these facts, this study analyzed mandibular measures of $C T$ scans of the FOP/UNICAMP Biobank, in order to determine the existence of sexual dimorphism and the ancestry of Brazilians from the Southeast region of Brazil.

\section{METHODS}

This research was designed and complies with the provisions of resolution 466/12 through the approval of CEP protocol 54171916.0 and CAAE 54171916.0.0000.5418 and sought to evaluate numerous linear measures of mandibles in CT scans of the FOP/UNICAMP Prof. Eduardo Daruge Osteological and Tomographic Biobank, as to dimorphism and ancestry. We also sought to develop logistic regression models to estimate sex and ancestry. 
All measurements were conducted using OnDemond3DTM software (Cybermed, Irvine, USA).

Inter- and intra-examiner test was performed to determine the calibration of the researcher. To that end, we measured 25 mandibles in CT scans properly identified for sex, ancestry, and age, three times each and at different times, to obtain and compare the percentage of margin of error.

After descriptive data analysis according to Szklo and Nieto [17], we found excellent agreement (ICC $\geq 0.75)$ both in inter-evaluator analysis and intra-evaluator analysis, for the measures described above. Once calibrated with standard of excellence, we finalized the other measurements completing 225 mandibles in CT scans.

For data analysis we used the IBM ${ }^{\circledR}$ SPSS ${ }^{\circledR} 25$ Statistics program. The sample consisted of the analysis of 225 CT scans of individuals (126 males, 94 females, and 5 unidentified) whose ages on date of death ranged from 18 to 100 years, by a single measurer. We excluded five scans
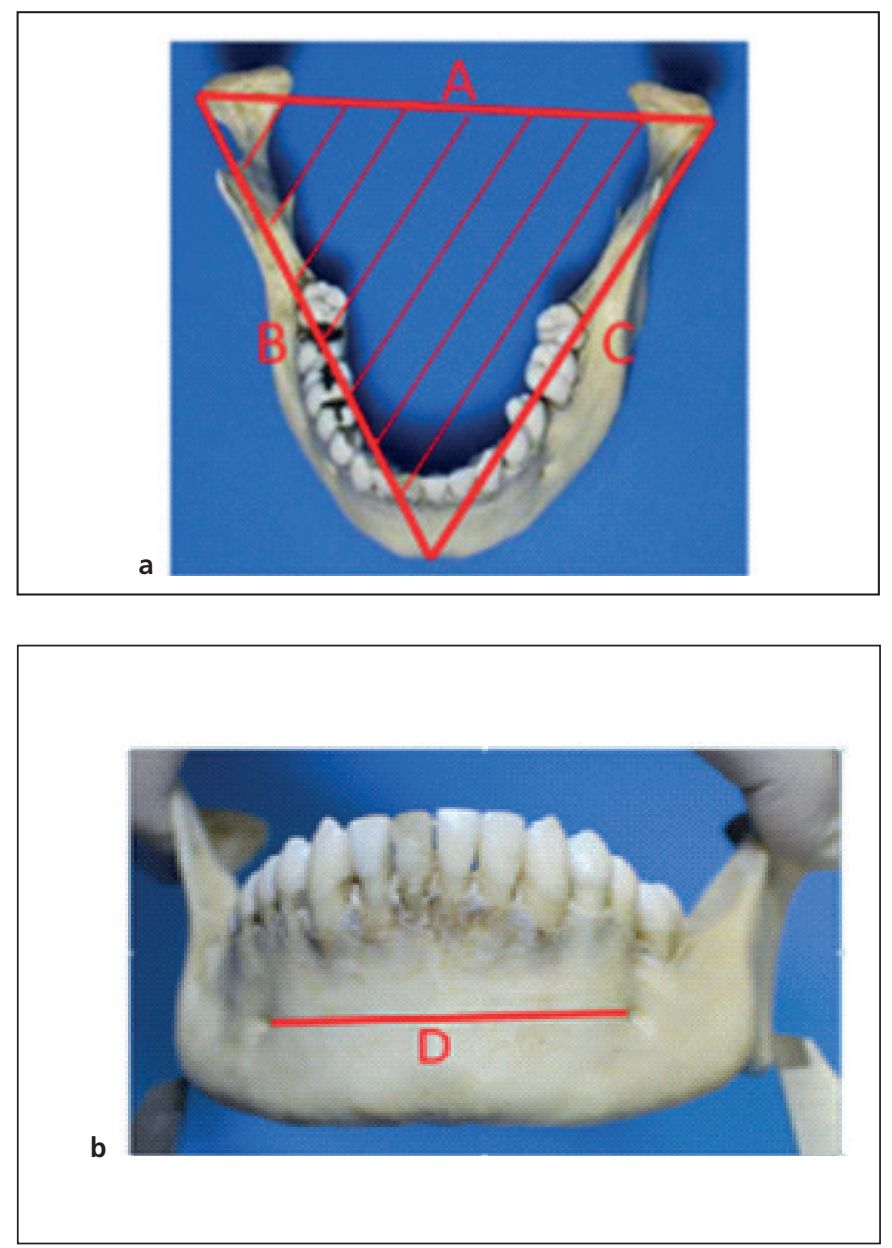

from these for not presenting identification of ancestry, totaling 220. Ancestry was catalogued according to skin color phenotype based on death records for leucoderma (white; $n=122$ ), phaioderma (brown; $n=67$ ), melanoderma (black; $n=30$ ) and xantoderma (yellow; $n=1$ ). The CT scans belong to the FOP-UNICAMP Prof. Eduardo Daruge Osteological and Tomographic Biobank. The CT scans were obtained using the Toshiba four-channel multslice tomography Scanner - "Toshiba Super 4, multslice Multi-Slice Quad CT with High Power Generator $48 \mathrm{~kW}$ CT generates 4 slices per revolution using the multi-row detector. 10 to $400 \mathrm{~mA} 0.5$ Second".

To determine the existence of sexual dimorphism and distinguishing characteristics of ancestry between mandibular measures of distances between right lateral condylion and left lateral condylion (A); right lateral condylion and pogonion (B); left lateral condylion and pogonion (C); mesial border of right mental foramen and mesial border of left mental foramen (D); area delimited by measures $A, B$, and $C(E)$; and age $(F)$, (figure 1 ), we

Figure 1. Representation of distances and area between study points (a) and (b); measures A, B, C, and D in CT (c) and (d). Source: archives of the researcher. 
performed statistical analyses that sought to establish a mathematical model able to estimate sex and ancestry. Schematically, the measurements carried out are shown in figures $1 \mathrm{a}$ and $1 \mathrm{~b}$. figures $1 \mathrm{c}$ and $1 \mathrm{~d}$ represent the measurements carried out in the OnDemand3 $\mathrm{D}^{\mathrm{TM}}$ software (Cybermed, Irvine, USA).

For data analysis we used the programs IBM $^{\circledR}$ SPSS ${ }^{\circledR} 25$ Statistics and R Program. The study presented sex as qualitative dependent variable; measures $A, B, C, D$, area, and age as quantitative independent variables; and ancestry (white, black, brown, and yellow) as qualitative independent variable.

After data normality and homoscedasticity was verified using Levene and Shapiro-Wilk test, respectively, descriptive analysis was performed using central tendency measures as mean and dispersion measures as standard deviation, minimum, and maximum of measures, as shown in table 1.

Student's t test, for sex, was conducted to test the hypotheses of nullity of the different variables under study, described below:
HO: Means A Female $=$ Means A Male

HO: Means B Female $=$ Means B Male

HO: Means C Female $=$ Means C Male

HO: Means D Female $=$ Means D Male

HO: Means Area Female = Means Area Male

\section{RESULTS}

Student's t test for homogeneous variances showed statistical difference in the means according to sex, as demonstrated in table 2.

We obtained 6 univariate models (table 2), which present as function:

$\operatorname{Prob}(Y=1): \frac{1}{1+\mathrm{e}^{-(\beta 0+\beta 1 \times 1)}}$.
.

Univariate regressions were performed according to Table 3.

The results demonstrated that the $\beta$ of measures $A, B, C$, and $D$ showed statistical significance, being

Table 1. Descriptive analysis.

\begin{tabular}{|c|c|c|c|c|c|}
\hline & $n$ & Minimum & Maximum & Mean & Standard deviation \\
\hline$A(m m)$ & 223 & 107,8 & 194,4 & 116,16 & 14,89 \\
\hline $\mathrm{B}(\mathrm{mm})$ & 223 & 98,2 & 134,9 & 113,51 & 7,00 \\
\hline$C(\mathrm{~mm})$ & 223 & 96,3 & 135,4 & 113,65 & 7,24 \\
\hline $\mathrm{D}(\mathrm{mm})$ & 219 & 34,7 & 55,5 & 43,84 & 3,65 \\
\hline Area $\left(\mathrm{mm}^{2}\right)$ & 223 & 4359,69 & 7916,29 & 5086,06 & 174,62 \\
\hline Age (years) & 225 & 15 & 100 & 59,22 & 20,51 \\
\hline
\end{tabular}

Table 2. Means (SD) of the variables according to sex.

\begin{tabular}{|c|c|c|c|c|c|}
\hline & Sex & $n$ & Mean & Standard deviation & $\mathrm{p}$-value of the Student's t test \\
\hline \multirow[b]{2}{*}{ A } & $\mathrm{F}$ & 93 & 112,23 & 21,21 & \multirow[b]{2}{*}{0,003} \\
\hline & $\mathrm{M}$ & 125 & 119,11 & 6,50 & \\
\hline \multirow[b]{2}{*}{$B$} & $\mathrm{~F}$ & 93 & 109,95 & 5,51 & \multirow[b]{2}{*}{0,000} \\
\hline & $M$ & 125 & 116,14 & 6,62 & \\
\hline \multirow[b]{2}{*}{ C } & $\mathrm{F}$ & 93 & v109,85 & 5,75 & \multirow[b]{2}{*}{0,000} \\
\hline & $M$ & 125 & 116,38 & 6,65 & \\
\hline \multirow[b]{2}{*}{ D } & $\mathrm{F}$ & 89 & 42,54 & 3,63 & \multirow[b]{2}{*}{0,000} \\
\hline & $\mathrm{m}$ & 125 & 44,87 & 3,37 & \\
\hline \multirow{2}{*}{ AREA } & $f$ & 94 & 4986,53 & 136,59 & \multirow[b]{2}{*}{0,445} \\
\hline & $\mathrm{M}$ & 126 & 5159,99 & 198,53 & \\
\hline
\end{tabular}


Table 3. Univariate logistic regression analysis for determination of sex.

\begin{tabular}{lccc}
\hline VARIABLE & $\beta_{0}$ & $\beta$ & $\begin{array}{c}p \text {-value } \\
\text { (Wald test) }\end{array}$ \\
\hline A & $-7,682$ & 0,007 & 0,002 \\
B & $-18,409$ & 0,017 & 0,000 \\
C & $-18,379$ & 0,017 & 0,000 \\
D & $-8,313$ & 0,02 & 0,000 \\
Area & 0,006 & 0 & 0,467 \\
\hline
\end{tabular}

selected for the establishment of the multiple model. The simple model for the area was not significant, so this was not selected for the multiple model.

\section{Multiple Logistic Regression Analysis}

The function of the multiple logistic regression models is presented below:

$$
\begin{aligned}
& \text { Prob }(Y=1): \quad 1 \\
& 1+\mathrm{e}^{-(\beta 0+\beta 1 X 1+\ldots \beta k X k)}
\end{aligned}
$$

To analyze the factors associated with the prediction of sex ( $Y=1$-Female) we performed a multiple logistic regression analysis in which we selected the variables with univariate model $p$-value $\leq 0.20$. The order of entry in the multiple model followed according to increasing $p$-values.

We tested 9 multiple logistic regression models using the Stepwise-forward selection strategy, which starts from the simplest model to the most complex model, adding the variables that obtained $p$-values under 0.20 , one by one, in increasing order of $p$. The order of entry in the multiple model followed the order: B, C, D, and A. In the decision for the best model, we established variables A and $\mathrm{D}$, as shown below and in table 4 .

$$
\begin{aligned}
& \text { Equation } \\
& \ln (p 1-p)=\beta 0+\beta 1 \times 1+\beta 2 \times 2+\beta 3 \times 3+\beta 4 \times 4
\end{aligned}
$$

Final model (logit)

$$
\ln (p 1-p)=-12,321+0,0045 \mathrm{~A}+0,017 \mathrm{D}
$$

In the residue analysis of the final model it was found that the errors of the logistic regression analysis are of binomial character. The residue analysis of the model considered as final was performed through the Hosmer and Lemeshow test, dividing into deciles, to evaluate whether

\begin{tabular}{|c|c|c|c|c|c|}
\hline \multirow{2}{*}{ A } & B & 120 & 116,09 & 11,8 & \multirow{2}{*}{0,925} \\
\hline & NB & 98 & 116,29 & 18,33 & \\
\hline \multirow{2}{*}{ B } & B & 120 & 113,14 & 6,86 & \multirow{2}{*}{0,392} \\
\hline & NB & 98 & 113,94 & 6,91 & \\
\hline \multirow{2}{*}{ D } & B & 116 & 43,53 & 3,64 & \multirow{2}{*}{0,11} \\
\hline & NB & 98 & 44,33 & 3,64 & \\
\hline \multirow{2}{*}{ AREA } & B & 120 & 6012,93 & 377,93 & \multirow{2}{*}{0,463} \\
\hline & NB & 98 & 5729,47 & 58,7 & \\
\hline
\end{tabular}
there is adherence of the final model. The final model

Table 4. Multiple logistic regression for determination of sex.

\begin{tabular}{lcccc}
\hline Variables & Coefficient & Standard error & Wald & p-value \\
\hline A & 0,004 & 0,005 & 13,877 & 0,0000 \\
D & 0,017 & 0,002 & 4,223 & 0,0400 \\
Constant & $-12,321$ & 2,863 & 15,518 & 0,0000 \\
\hline
\end{tabular}

Table 5. Means (SD) of the variables according to ancestry. 
test was of 0.802 , showing a good adherence of the final model, which demonstrated an accuracy of $69.2 \%$.

For the study of ancestry, subjects were divided into two groups: whites and non-whites. Student's t test was conducted to test the hypotheses of nullity of the different variables under study, described below: For homogeneous variances there was no statistical difference in the means according to ancestry, as shown in table 5 :

$H 0$ : Means $A B=$ Means ANB

HO: Means $B B=$ Means BNB

$\mathrm{HO}$ : Means $\mathrm{CB}=$ Means $\mathrm{CNB}$

$\mathrm{HO}$ : Means $\mathrm{DB}=$ Means DNB

HO: Means AreaB $=$ Means AreaNB

In the logistic regression for ancestry we obtained 6 univariate models, which presents as function:

$\operatorname{Prob}(Y=1): \frac{1}{1+e^{-(\beta 0+\beta 1 \times 1)}}$.

Univariate regressions were conducted. The simple model for the measures and for the area was not significant for ancestry, demonstrating that there are no differences in measures according to ancestry. Therefore, the measures examined cannot be considered regressors to predict ancestry.

\section{DISCUSSION}

Poulsen and Simonsen [17] reported that computerized tomography was introduced as routine in autopsies at the Institute of Forensic Medicine in Copenhagen, Denmark, in December 2002, and with the data obtained (4,000 evidence found) they created a bank.

It is known that three-dimensional images allow easy location of ballistic projects, and are considered better when compared with traditional x-ray examinations [18].

Such situation is already reality and the justice will increasingly request expert examinations that ensure quality combined with the obtainment of uncontestable evidence [4]. Thus, it is believed that x-ray exams will be gradually replaced in all institutes of Forensic Medicine and Forensic Dentistry, aiming at improved diagnosis of lesions in alive (corpus delicti examinations) and examinations in corpses (integral and/or skeletons).
Meanwhile such CT examinations can be used in Forensic physical Anthropology, in exams to estimate ancestry, age, and sex [4].

The acknowledged most dimorphic bones are the pelvis, cranium, and mandible [12], in this order. The mandible is the essential bone in the process of communication (speech), mastication, and social appearance (aesthetics), and also allows, by its size, classifying the specific ancestry of each individual [15], and is also, by its constitution and form, one of the most recovered in crime scenes; therefore, sex estimation in a coherent analysis cannot disregard it [1].

It is known that Brazilian born individuals are of mixed race (Europeans, Africans, and Amerindians) and the differential features mixed, thus there is no typical and unique Brazilian standard.

The study conducted enabled demonstrating that there is sexual dimorphism in the linear measures between right lateral condylion and left lateral condylion $(\mathrm{A})$; right lateral condylion and pogonion (B); left lateral condylion and pogonion (C); mesial border of right mental foramen and mesial border of left mental foramen (D), obtained by CT scans, allowing to establish sex by means of a mathematical model. This fact was also obtained by other researchers $[12,14]$. It is noted that in a study [12] of 250 dry and integral human mandibles, of population of southern India, it was found that bigonial width, bicondilar width, and mandibular length were also dimorphic.

However, significant results were not obtained when estimating sex by mandibular area, with these values not being predictive for this function.

It is believed that in non-mixed-race populations, mandibular area study is significant and can be used in sex determination.

When analyzing the influence of these measures on the study of ancestry, it was found that they showed no difference.

A regression model was created for sex estimation, with $69.2 \%$ success rate. This index is consistent with those obtained by Garvin, Sholts, and Mosca [13], who obtained $74-94 \%$ success rate and $85 \%$ overall accuracy for the combined sample. The same occurred in the study of İlgüy et al. [14], who obtained success rates of $77.3 \%$ for males and $87.4 \%$ for females. 
Gamba et al. [15] obtained correct classification with the discriminant function for male individuals of $93.3 \%$ and for female individuals of $94.7 \%$; although these indexes are considered ideal, they do not correspond to the Brazilian reality, as there is a value of $10 \%$ to $20 \%$ of individuals that are not differentiated due to great race mixing. It is believed that the sample under study presents little race mixing with quite pronounced dimorphic characteristics.

The model obtained in this study will generate a software that can be applied to skeletons of Brazilians, in the absence of models obtained from regional samples. The same, due to its sample origin can provide better applicability for sex estimation in mandibles of individuals from southeastern Brazil.

This software may be made available free of charge to forensic experts, which will lead to gains in time and reliability of results.

\section{CONCLUSION}

For sexual dimorphism analysis, the linear measures between right lateral condylion and left lateral condylion; right lateral condylion and pogonion; left lateral condylion and pogonion; and mesial border of right mental foramen to mesial border of left mental foramen showed to be effective; the area delimited by the first three measures provided no advantage in the prediction of sex. The same measures presented no statistical differences for applicability in ancestry determination.

It was possible to develop a mathematical model to determine sex, with $69.2 \%$ success rate, in which the significant measures were those between right lateral condylion and left lateral condylion (A) and mesial border of right mental foramen and mesial border of left mental foramen (D).

\section{Collaborators}

RTP ISHIGAME, investigation; data curation; writingoriginal draft. A PICAPEDRA, C SASSI and V ULBRICHT, writingreview \& editing. E DARUGE JÚNIOR, funding acquisition, writing-review \& editing. VGA PECORARI, formal analysis. F HAITER NETO, conceptualization; validation. L FRANCESQUINI JÚNIOR, conceptualization, methodology, project administration, software, supervision, writing-review \& editing.

\section{REFERENCES}

1. França GV. Medicina Legal. 10th ed. Rio de Janeiro: Editora Guanabara Koogan; 2015.

2. Interpol. Interpol [online] [cited 2015 Dez 06]. Available from: <www.interpol.int/INTERPOLexpertise/Forensics/DVI-pages/ DVI-guide>.

3. Coutinho CGV, Ferreira CA, Queiroz LR, Gomes LO, Silva UA. O papel do odontolegista nas perícias criminais. Rev Odonto. 2013;18(2):217-223. http://dx.doi.org/10.5335/rfo. v18i2.3399

4. Daruge E, Daruge Júnior E, Francesquini Júnior L. Tratado de Odontologia legal e deontologia. Rio de Janeiro: Guanabara Koogan; 2017.

5. Zeferino $A M B$, Barros Filho $A A B$, Bettiol $H$, Barbieri MA. Acompanhamento do crescimento. J Pediat. 2003;79(suppl.1):S23-S32. http://dx.doi.org/10.1590/S0021-7 5572003000700004

6. Prado WL, Botero JP, Guerra RLF, Rodrigues CL, Cuvello LC, Dâmaso AR. Perfil antropométrico e ingestão de macronutrientes em atletas profissionais brasileiros de futebol, de acordo com suas posições. Rev Bras Med Esporte. 2006;12(2):61-65. http://dx.doi.org/10.1590/S151786922006000200001

7. lida I. Ergonomia: projeto e produção. São Paulo: Edgard Blücher; 2001.

8. Francisco RA, Velloso APS, Silveira TCP, Secchieri JM, Guimarães MA. Antropologia forense no Centro de Medicina Le Medicina Legal da FMRP/USP, estudo comparativo de casos de 1999-2009. Rev Fac Med Ribeirão Preto Hosp Clínicas da FMRP. 2011;44(3):241-8. http://dx.doi.org/10.11606/issn.21 76-7262.v44i3p241-248

9. Oliveira RN, Daruge E, Galvão LCC, Tumang AJ. Contribuição da odontologia legal para a identificação "post-mortem". Rev Bras Odontol. 1998;55(2):117-122.

10. Carvalho SPM, Silva RHA, Lopes-Júnior C, Peres AS. A utilização de imagens na identificação humana em odontologia legal. Radiol Bras. 2009;42(2):125-130. http://dx.doi.org/10.1590/S0 100-39842009000200012

11. Franklin D, Cardini A, Flavel A, Kuliukas A. A aplicação das tradições tradicionais análises morfométricas geométricas para quantificação forense de dimorfismo: investigações preliminares em uma população da Austrália Ocidental. Int J Med. Juríd. 2012;126(4):549-58. http://dx.doi.org/10.1007/s0 0414-012-0684-8

12. Vinay G, Mangala Gowri SR, Anbalagan J. Sex determination of human mandible using metrical parameters. J Clin Diagn Res. 2013;7(12):2671-2673. http://dx.doi.org/10.7860/JCDR/2 013/7621.3728

13. Garvin HM, Sholts SB, Mosca LA. Sexual dimorphism in human cranial trait scores: effects of population, age, and body size. Am J Phys Anthropol. 2014;154(2):259-269. http:// dx.doi.org/10.1002/ajpa.22502

14. İlgüy $D$, İlgüy $M$, Ersan N, Dölekoğlu S, Fişekçioğlu E. Measurements of the foramen magnum and mandible in 
relation to sex using CBCT. J Forensic Sci. 2014;59(3):601-5. http://dx.doi.org/10.1111/1556-4029.12376

15. Gamba TDO, Alves MC, Haiter-Neto F. Mandibular sexual dimorphism analysis in CBCT scans. J Forensic Leg Med. 2016;38:106-10. http://dx.doi.org/10.1016/j.jflm.2015.11.024

16. Santos RMG, De Martino JM, Haiter Neto F, Passeri LA. Cone beam computed tomography-based cephalometric norms for Brazilian adults. Int J Oral Maxillofac Surg. 2018;47(1):64-71. http://dx.doi.org/10.1016/j.ijom.2017.06.030

17. Poulsen K, Simonsen J. Computed tomography as routine in connection with medico-legal autopsies. Forensic Sci Int. 2007;171:190-7. http://dx.doi.org/10.1016/j.forsciint.2006.05.041
18. Thali MJ, Yen K, Vock P, Ozdoba C, Kneubuehl BP, Sonnenschein $\mathrm{M}$, et al. Image-guided virtual autopsy findings of gunshot victims performed with multi-slice computed tomography (MSCT) and magnetic resonance imaging (MRI) and subsequent correlation between radiology and autopsy findings. Forensic Sci Int. 2003;138(1-3):8-16. http://dx.doi. org/10.1016/S0379-0738(03)00225-1

Received on: 22/2/2018

Final version resubmitted on: 3/4/2018

Approved on: 19/11/2018 